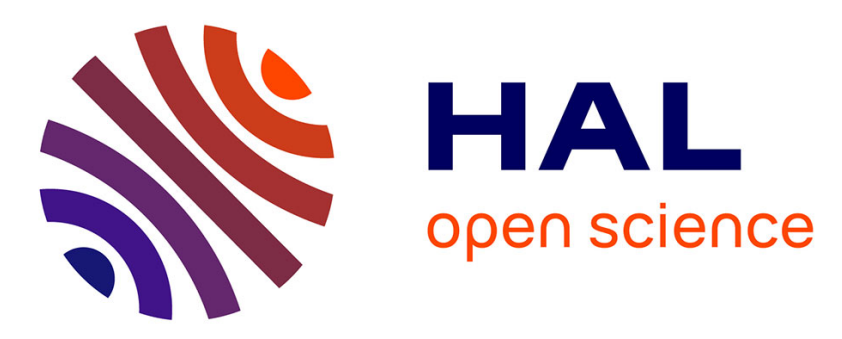

\title{
A school-based universal programme to prevent depression and to build up life skills
}

Melanie Silvia Wahl, Margarete Anne Patak, Patrick Pössel, Martin

Hautzinger

\section{- To cite this version:}

Melanie Silvia Wahl, Margarete Anne Patak, Patrick Pössel, Martin Hautzinger. A school-based universal programme to prevent depression and to build up life skills. Journal of Public Health, 2011, 19 (4), pp.349-356. 10.1007/s10389-011-0400-z . hal-00616702

\section{HAL Id: hal-00616702 \\ https://hal.science/hal-00616702}

Submitted on 24 Aug 2011

HAL is a multi-disciplinary open access archive for the deposit and dissemination of scientific research documents, whether they are published or not. The documents may come from teaching and research institutions in France or abroad, or from public or private research centers.
L'archive ouverte pluridisciplinaire HAL, est destinée au dépôt et à la diffusion de documents scientifiques de niveau recherche, publiés ou non, émanant des établissements d'enseignement et de recherche français ou étrangers, des laboratoires publics ou privés. 
Melanie S. Wahl, Margarete A. Patak, Patrick Pössel, Martin Hautzinger

\section{A School-based Universal Programme to Prevent Depression and to Build Up Life Skills}

Melanie S. Wahl, Margarete A. Patak, \& Martin Hautzinger

Department of Clinical and Developmental Psychology, University of Tübingen, Tübingen

Christophstr. 2

72072 Tübingen

Germany

Patrick Pössel

Department of Educational and Counseling Psychology, University of Louisville,

2301 S. $3^{\text {rd }}$ Street

Louisville, KY 40292

USA

Corresponding author:

Melanie S. Wahl

e-mail: melanie.wahl@psycho.uni-tuebingen.de

phone: +49-7071-2978294

fax: +49-7071-295517

Original article 


\title{
A School-based Universal Programme to Prevent Depression and to Build Up Life Skills
}

\begin{abstract}
:
Aim: To prevent the development and increase of depressive symptoms in adolescents by empowering adolescents to improve their life skills, to foster their realistic thinking, and to influence school behaviour.

Subjects and Methods: Vocational track students in grade 8 from the southwest of Germany participated either in a school-based universal prevention programme or a teaching as usual control group condition. The cognitive-behavioural programme LARS\&LISA includes 10 sessions held in a regular school setting in same-gender groups. The programme is based on the social informationprocessing model of social competence (Dodge 1993) and consists of five basic elements: (1) Formulation and setting of personal goals; (2) Relationship between cognitions, emotions and behaviour; (3) Exploration and change of dysfunctional cognitions; (4) Training of social competence; (5) Assertiveness training.

Results: The programme is extensively evaluated in three studies and has shown positive effects on the participants' social network, symptoms of depression and aggressive behaviour compared to teaching as usual.

Conclusions: We have demonstrated that the programme can be successfully delivered to students in a higher vocational track of school ("Realschule") by psychologists. Currently it is evaluated in a lower vocational track of school ("Hauptschule") by teachers and psychologists. With LARS\&LISA we provide a prevention strategy that can be successfully delivered to a school-based population and integrated into classroom curriculum.
\end{abstract}

Key Words: school-based prevention; depression; adolescents; cognitive-behavioural programme; life skills 


\section{Introduction}

\section{Adolescents and Depression}

Depressive disorders in adolescents are a widespread and increasing problem with extensive psychosocial consequences and high costs for society. Epidemiological studies report prevalence rates of up to 20\% (Birmaher et al. 1996; Bettge et al. 2008). Research indicates that even depressive symptoms that do not reach clinical level in adolescents are strongly associated with an increased risk of developing a depressive disorder and other psychopathologies in adulthood (Georgiades et al. 2006; Birmaher et al. 1996). Vocational track ("Haupt- und Realschule") students have an increased risk of developing depressive disorders (Fend and Schröer 1990) compared to academic track ("Gymnasium") students. This is consistent with the findings that household income is an important predictor of students depressive symptoms (Goodman et al. 2003) and socioeconomic status is a main predictor for students attending a vocational track school (Bos et al. 2004). Therefore, students from a vocational track of schooling represent a risk population for the development and chronification of depressive disorders while simultaneously these students are hardly reached by usual health care (Spoth et al. 1999).

The World Health Organization (2004) describes prevention as one of the most effective strategies to reduce the burden associated with psychological diseases. Prevention can be divided into three types: universal, selected, and indicated programmes. Indicated interventions target children and adolescents identified with mild to moderate symptoms of a disorder, selective strategies involve individuals identified as at risk of psychological problems while universal prevention programmes can be applied to a whole population regardless of their risk status or the development of early psychological symptoms. Therefore universal prevention programmes can be delivered in a regular school curriculum and are associated with other advantages, including the loss of screening problems, recruitment attrition difficulties and stigmatization (Offord 2000). Empirical support for preventive strategies conducted in school settings is growing. Especially encouraging are results showing no difference in effectiveness of a universal prevention programme between students from different socioeconomic groups (Merry et al. 2004). For the prevention of depression there are some evaluated universal programmes available (e.g. the Resourceful Adolescent Programme - RAP, Shochet et al. 2001; or the Problem Solving for Life Programme - PSFL, Spence et al. 2003). There are also evaluated programmes which target both anxiety and depression (e.g. Gesundheit und Optimismus GO!, Junge et al. 2002; or FRIENDS, Barrett et al. 2000). We describe in this article our own, successfully evaluated, universal programme to prevent the development of depressive symptoms in adolescents (LARS\&LISA; Pössel et al. 2004b). 


\section{Theoretical background}

On what universal prevention programmes should focus

The social information-processing model of social competence developed by Dodge (1993) represents a convincing rational for (universal) prevention programmes and psychological interventions. According to this model behaviour in reaction to situational stimuli is the consequence of an information-processing sequence with five stages: encoding, mental representation, response accessing, response evaluation and selection and enactment. In the encoding stage selective perception filters relevant aspects of the stimulus, which are then stored in short-term memory. Stimuli are stored in memory primarily according to their significance for the individual ("mental representation"). Significance is connected with the individual's emotional needs and intentions. On this basis emotional and behavioural reactions are generated in the stage of response accessing. Various mental representations are connected with different reactions like physical activity, verbalisation, endocrine secretion, arousal of the autonomous systems and affect based on rules of the associative network of the brain (for example "cry when rejected"). In the response evaluation and selection the individual evaluates the prepared reactions and decides on one of the alternatives, depending on moral, acceptability and/or anticipated consequences. If the criteria are not met, the process of decision is repeated until a suitable reaction can be chosen. If this evaluation succeeds, the decision can be initiated on in the final stage (enactment), which can take on the form of verbalisation, physical activity, autonomous activity, and other reactions, which can be seen or measured.

Dysfunctional interpretations of situational stimuli, emotional reactions, and withdrawal from social situations are a result of malfunction of one or more information-processing stages. Different studies could show that the information-processing of children with increased depressive symptoms is deficient, for example they showed more negative and less positive social information processing (Bell et al. 2009). Depressive information processing predicted the level of depression of adolescents a year later (Pössel et al. 2006b). Prevention programmes, therefore, should focus on the biased information processing as a modifiable feature and show the relationship to emotional responses and social behaviour. In a further step assertive behaviour as well as social competence skills should be trained to provide for alternative responses.

To gather momentum for change it is expedient to focus on as many levels of social information processing as possible. For the encoding stage self-observation and situational analyses help to become aware of functional relationship and improve perceptual skills. On the mental representation stage social stimuli are interpreted. In order to motivate for change, it is necessary to develop an understanding of the key concepts through exploring the relationship between cognition, emotion, and behaviour (LARS\&LISA programme element "Reversible Spiral"). Social stimuli attributions are targeted by identifying dysfunctional, automatic thoughts and by replacing them with more functional thoughts (LARS\&LISA programme element "Think"). To establish functional response alternatives on the response accessing and response evaluation and selection stage youths can experience various 
functional response alternatives and their positive consequences in a skill and competence training (LARS\&LISA programme element "Just do it") and a social approach (LARS\&LISA programme element "Get in touch"). These modules build up self-confidence and provide behaviour which is incompatible with social withdrawal. The most important element of the social part of a training programme is role-play because it simultaneously allows modification on both stages of information processing. Adolescents can experiment with new and more functional response alternatives and observe and experience their own and others' reactions to these. At the same time, as a further step, the translation of the new response options into actual behaviour is accomplished

In addition to these basic elements that need to be accomplished by effective prevention programmes, a motivational component for active participation is necessary (LARS\&LISA programme element "Set your goals"). Participants should develop their personal goals, work out how to formulate them and what they can do to reach their goals step by step, starting from now on. Goals should be specific, measurable, and divisible into sub-goals. It is important that the progress of achievement is frequently observed. It is advisable for group members to report their personal gains at the end of each session considering why and how the programme contents are helpful in reaching that personal goal. Adolescents experience that they themselves can be active in influencing their life and well-being and develop a sense of self-efficacy. A successful universal prevention programme should include the main components presented in figure 1 .

Please insert figure 1 here.

\section{Method}

The universal prevention programme of depression: LARS\&LISA

In German two different versions of the prevention programme exist, one version for groups of higher vocational track ("Realschule") students (LARS\&LISA; Pössel et al. 2004b) and one for lower vocational track ("Hauptschule") students (Lebenslust mit LARS\&LISA ${ }^{1}$ ). In addition, there exists a version for high-school students in the USA. All three versions are identical in regard to the contents of the sessions, they vary in a different degree of complexity of language and difficulty of tasks according to the academic level of the target population and the layout and pictures of the peer coping models, which are ethnically matched to the audience. In the following the basic programme contents of the three versions are described more precisely.

LARS\&LISA is delivered to students $8^{\text {th }}$ grade or higher ( $\geq 13$ years of age) once a week over a 10week period during regular school hours. One session is composed of two 45-minute class periods for a total of 1.5-hours per session. The programme is administered to students in same-gender groups

\footnotetext{
${ }^{1}$ Available at http://www.uni-tuebingen.de/psychologie/abtkpps/lars_und_lisa/materialien.htm
} 
because adolescents may be hesitant to portray themselves authentically in front of peers of the other sex. In fact, for boys, research has shown that sex-homogeneous groups can create contexts in which boys can share feelings and emotions without embarrassment (Sukhnandan et al. 2000), be less distracted, and be more open and responsive without fear of compromising their "laddish" image in front of girls (Warrington and Younger 2003). Furthermore, a pilot study has shown that adolescents in this age group work more effectively and openly as a team if they participate in same-sex groups (Pössel et al. 2003). LARS\&LISA can be led by one or two group leaders and by psychologists or teachers with equal outcome in same-gender groups. Groups with 8 to 12 students are ideal but the programme also works with smaller (4) and bigger (up to 20) groups (Pössel et al. 2004b). Following table 1 shows the elements of each session.

Please insert table 1 here.

For facilitation of programme elements, educational film models are available with adolescents functioning as actors in different situations (German programme versions only). Subjective of these film trailers is to enlarge knowledge about social situations and adaptive social behaviour, to enhance motivation for change by identification with peers (Lars and Lisa) acting as coping models. Students learn that their well-being and behaviour is not necessarily predetermined by an external situation but instead by their own cognitions and behaviour which can be influenced. The films are also a tool to loosen up the lesson in order to keep up concentration and active participation.

\section{Main session contents}

The group leader manual describes the content of every session in a self-explanatory way and in great detail. Each session follows the same structure, which is summarized on the first page (including material list, session goals and suggested timing) for each training session. The sessions begin by making a semi-circle, review the knowledge quiz, which was filled in at the end of the previous session, and a presentation of the topic of each session. Then the specific session content is worked on, to be concluded with making connections and the feedback at the end of the session. In the following these elements will be specified.

Before the start of the session, we recommend to form a semi-circle with the group members in order to create a more open atmosphere and encourage teamwork. Another advantage of the semi-circle is that it helps to distinguish from the regular school curriculum seating plan. Some classes may require a usual seating plan in order to keep up a work-oriented atmosphere (especially boys' groups). Another method used in every session is the knowledge quiz, which is handed out at the end of each session. The group leader corrects the quiz by the next session and gives positive feedback (positive reinforcement) to the whole group at the beginning of the following session. Main purpose of the knowledge quiz is to check whether the material of the session has been understood by the students 
and if not, to review corresponding contents. The topic of each session as well as session goals are presented as an overview before the actual session programme starts, in order to arouse participants' interests and to connect former and following lessons. Making connections is the most important content of each session. Students are invited to find examples how they can use what they have learned this session in their every-day life and how they can reach their goals this way. It shows students how LARS\&LISA can influence their everyday lives and aims to encourage members to use the strategies and to maintain motivation for active participation. At the end of each session, group leaders are advised to give feedback to the group regarding their observance of the group guidelines. Feedback should always be positive and reinforcing using specific examples without activating reactance that may result from negative feedback.

\section{Suggested coaching style and group leader qualifications}

In the manual we give suggestions regarding group leader behaviour which results out of years of work with the LARS\&LISA programme. A group leader needs to have knowledge of cognitive and learning theory and should have knowledge of social skills training and experience in working with adolescents. We recommend attending a training workshop for group leaders. Basic guidelines for coaching style include: goal transparency, ensure understanding of theoretical background, differentiation of knowledge-related and personal questions, handling of wrong students answers, positive reinforcement and handling of difficult group interaction. In addition, one chapter of the group leader manual includes a summary of pedagogical background: prevention of disturbance by activation, lesson flow, precise guidelines and presence and stop signals. To help to get started, several "Ice Breakers" (Get to know games) are described in the manual. Every session also includes a game with regards to the content of the session.

\section{What do the LARS\&LISA sessions look like?}

To illustrate the approach of LARS\&LISA two sessions shall be described in detail. In session 3 ("Reversible Spiral - I") the students practise identifying thoughts and feelings. They learn how thoughts, feelings and behaviour are associated. The concept of dysfunctional and functional thoughts (called "down-thoughts" and "up-thoughts") are introduced.

Differentiation between thoughts, feelings, and behaviour is developed with the help of examples and elaborated through several exercises like an emotion charade, in which the adolescents pantomime an emotion and the group postulates which situation, thoughts, and actions could accompany these. The aim of this session is that it becomes apparent to the adolescents that the same situation can lead to very different feelings depending on the interpretation of the situation, and by this mechanism the adolescents can influence their own emotional condition.

In the worksheet shown below (figure 2) the relationship between cognitive, emotional, and behavioural variables is illustrated by a reversible spiral. With an example drawn from the life of the 
adolescents like the following adolescents can understand the impact of functional and dysfunctional thoughts: A student receiving a bad grade in a maths-test can either react with "down-thoughts" ("I am too stupid, I will never understand maths"), feelings of despair and depression and avoidance of maths with the result of further deterioration in that subject, or with "up-thoughts" ("I was not prepared well enough for this test, I will ask my friend to explain the subject to me and start learning for the next test"), which lead to better coping and confidence with functional behaviour like increased effort. In the following sessions the concept of the "reversible spiral" is recessed with multiple methods, for example a film story where Lars has "down-thoughts" which block the progress toward a goal. The conclusion is drawn that situations can not always be changed, but the way we think about situations can be controlled.

In the knowledge quiz the students are invited to apply this scheme to a situation of their own life. Like each session this one ends with the embedding of the new issues in the daily life of the adolescents by making connections with different situations, how they can transfer the achieved knowledge into practice, and by referring to the example from the film model.

Please insert figure 2 here.

In session 7, our second example for a specific session, the emphasis is on social skills. First, several social situations described by the students as potentially difficult for some people (not necessarily difficult for themselves) are collected. With the help of three scenes from a film, in which a youth acts in the same situation in an either passive, aggressive, or assertive way, students develop an understanding of how to identify different types of behaviour based on voice, eye contact, body language, and speech content (figure 3).

Please insert figure 3 here.

Then the pros and cons of the different types of behaviour are discussed with a focus on the short-term pros of aggressive and passive behaviour, which the students experience in their every-day situations. At the same time, the discussion focuses on the long-term disadvantages of aggressive and passive behaviours. The aim of this strategy to discuss aggressive and passive behaviours is that adolescents realize that only assertive behaviour leads to positive long-term consequences by respecting yourself as much as the counterpart. This session creates the basis in knowledge, skills, and motivation for the practical implementation through role-play in the following sessions. 


\section{Results}

The school based universal prevention programme LARS\&LISA is extensively evaluated by three studies with German adolescents and one study with American high-school students. LARS\&LISA has shown positive effects on the participants`social network (Pössel et al. 2003), symptoms of depression (Pössel et al. 2005; Pössel et al. 2004a; Pössel et al. 2008), and aggressive behaviour (Groen et al. 2003), compared to teaching as usual as well as compared to a prevention programme based on Pennebaker's paradigm of expressive writing (Pössel et al. 2006a). In addition, the LARS\&LISA programme for lower vocational track students is in the process of evaluation, showing first promising results regarding the implementation of the programme through teachers as group leaders.

\section{Outlook}

The LARS\&LISA evaluation study with lower vocational track students currently demonstrates high response rates (more than $85 \%$ so far) at 12-month follow-up assessment. The projected 18-month follow-up is expected to be difficult as the participating students will by then have already left school and therefore be hard to reach.

Besides the acquisition of knowledge, education and advancement of cognitive skills, school should also address social learning and social skills for every day life, to empower resources and resilience, and to train coping strategies. By this, school can strengthen positive attitudes towards life, enhance emotion regulation and self-efficacy and consequently, foster health and the prevention of health problems. With LARS\&LISA an attractive and well evaluated universal prevention programme is available in different versions for the specific needs of $8^{\text {th }}$ grade boys and girls (13-14 years) in diverse school settings. It can be easily implemented, is highly manualised, and provides didactic materials and exercises which allow the possibility of teachers to be group leaders. 


\section{References}

Barrett PM, Lowry-Webster H, Turner C (2000) Friends program for children: Participants workbook. Australian Academic Press, Brisbane

Bell DJ, Luebbe AM, Swenson LP, Allwood MA (2009) The children's evaluation of everyday social encounters questionnaire: Comprehensive assessment of children's social information processing and its relation to internalizing problems. Journal of Clinical Child \& Adolescent Psychology 38 (5):705-720

Bettge S, Wille N, Barkmann C, Schulte-Markwort M, Ravens-Sieberer U (2008) Depressive symptoms of children and adolescents in a german representative sample: Results of the bella study. European Child \& Adolescent Psychiatry 17 (1):71-81

Birmaher B, Ryan N, Williamson D, Brent D, Kaufman J, Dahl R, Perel J, Nelson B (1996) Childhood and adolescent depression. A review of the past 10 years, part i. Journal of the American Academy of Child \& Adolescent Psychiatry 35 (11):1427-1439

Bos W, Voss A, Lankes E-M, Schwippert K, Thiel O, Valtin R (2004) Schullaufbahnempfehlungen von Lehrkräften für Kinder am Ende der vierten Jahrgangsstufe. In: Bos W, Lankes E-M, Prenzel M, Schwippert K, Valtin R, Walther G (eds) Iglu. Einige Länder der Bundesrepublik Deutschland im Vergleich. Waxmann Verlag GmbH, Münster, pp 191-228

Dodge KA (1993) Social-cognitive mechanisms in the development of conduct disorder and depression. Annual Review of Psychology 44:559-584

Fend H, Schröer S (1990) Depressive Verstimmungen in der Adoleszenz. Verbreitungsgrad und Determinanten in einer Normalpopulation. In: Steinhausen H-C, Albrecht HT (eds) Das Jugendalter. Entwicklungen. Probleme. Hilfen. Huber, Bern, pp 58-86

Georgiades K, Lewinsohn PM, Monroe SM, Seeley JR (2006) Major depressive disorder in adolescence: The role of subthreshold symptoms. Journal of the American Academy of Child \& Adolescent Psychiatry 45 (8):936-944

Goodman E, Slap GB, Huang B (2003) The public health impact of socioeconomic status on adolescent depression and obesity. American Journal of Public Health 93 (11):18441850. doi:10.2105/ajph.93.11.1844

Groen G, Pössel P, Al-Wiswasi S, Petermann F (2003) Universelle, schulbasierte Prävention der Depression im Jugendalter: Ergebnisse einer Follow-Up-Studie. Kindheit und Entwicklung 12 (3):164-174

Junge, Neumer, Manz, Margraf (2002) Gesundheit und Optimismus. GO! Trainingsprogramm für Jugendliche. Beltz, Weinheim

Merry S, McDowell H, Wild CJ, Bir J, Cunliffe R (2004) A randomized placebo-controlled trial of a school-based depression prevention program. Journal of Amer Academy of Child \& Adolescent Psychiatry 43 (5):538-547

Offord DR (2000) Selection levels of prevention. Addictive Behaviors 25 (6):833-842

Pössel P, Baldus C, Horn AB, Groen G, Hautzinger M (2005) Influence of general selfefficacy on the effects of a school-based universal primary prevention program of depressive symptoms in adolescents: A randomized and controlled follow-up study. Journal of Child Psychology \& Psychiatry 46 (9):982-994

Pössel P, Horn AB, Groen G, Hautzinger M (2004a) School-based prevention of depressive symptoms in adolescents: A 6-month follow-up. Journal of the American Academy of Child and Adolescent Psychiatry 43 (8):1003-1010

Pössel P, Horn AB, Hautzinger M (2003) Erste Ergebnisse eines Programms zur schulbasierten Prävention von depressiven Symptomen bei Jugendlichen. Zeitschrift für Gesundheitspsychologie 11 (1):10-20

Pössel P, Horn AB, Hautzinger M (2006a) Vergleich zweier schulbasierter Programme zur Prävention depressiver Symptome bei Jugendlichen. Zeitschrift für klinische Psychologie und Psychotherapie 35 (2):109-116 
Pössel P, Horn AB, Seemann S, Hautzinger M (2004b) Trainingsprogramm zur Prävention von Depressionen bei Jugendlichen. LARS\&LISA. Lust an realistischer Sicht \& Leichtigkeit im sozialen Alltag. Hogrefe, Göttingen

Pössel P, Seemann S, Ahrens S, Hautzinger M (2006b) Testing the causal mediation component of dodge's social information processing model of social competence and depression. Journal of Youth and Adolescence 35:849-859

Pössel P, Seemann S, Hautzinger M (2008) Impact of comorbidity in prevention of adolescent depressive symptoms. Journal of Counseling Psychology 55 (1):106-117

Shochet IM, Dadds MR, Holland D, Whitefield K, Harnett PH, Osgarby SM (2001) The efficacy of a universal school-based program to prevent adolescent depression. Journal of Clinical Child Psychology 30 (3):303-315

Spence SH, Sheffield JK, Donovan CL (2003) Preventing adolescent depression: An evaluation of the problem solving for life program. Journal of consulting and clinical psychology 71 (1):3-13

Spoth R, Goldberg C, Redmond C (1999) Engaging families in longitudinal preventive intervention research. Discrete-time survival analysis of socioeconomic and socialemotional risk factors. Journal of Consulting and Clinical Psychology 67 (1):157-163. doi:10.1037/0022-006x.67.1.157

Sukhnandan L, Lee B, Kelleher S (2000) An investigation into gender differences and achievement: Phase 2. School and classroom strategies. National foundation for educational research. Slough, England

Warrington M, Younger M (2003) 'we decided to give it a twirl': Single-sex teaching in english comprehensive schools. Gender and Education 15 (4):339-350

World Health Organization (2004) Prevention of mental disorders. Effective interventions and policy options. 


\section{Acknowledgments}

Research supported by German Research Foundation (DFG) and Federal Ministry of Education and Research (BMBF).

\section{Conflict of interests}

The authors declare that they have no conflict of interest. 
Table 1: Contents of the LARS\&LISA prevention programme 
Fig. 1: The main elements of a universal prevention programme (adapted from Pössel et al. 2004b)

Fig. 2: Exemplary Worksheet for a cognitive session: "Reversible Spiral” (adapted from Pössel et al. 2004b)

Fig. 3: Exemplary Worksheet for a social session: different types of behaviour (adapted from Pössel et al. 2004b) 


\section{Elements of a prevention program}

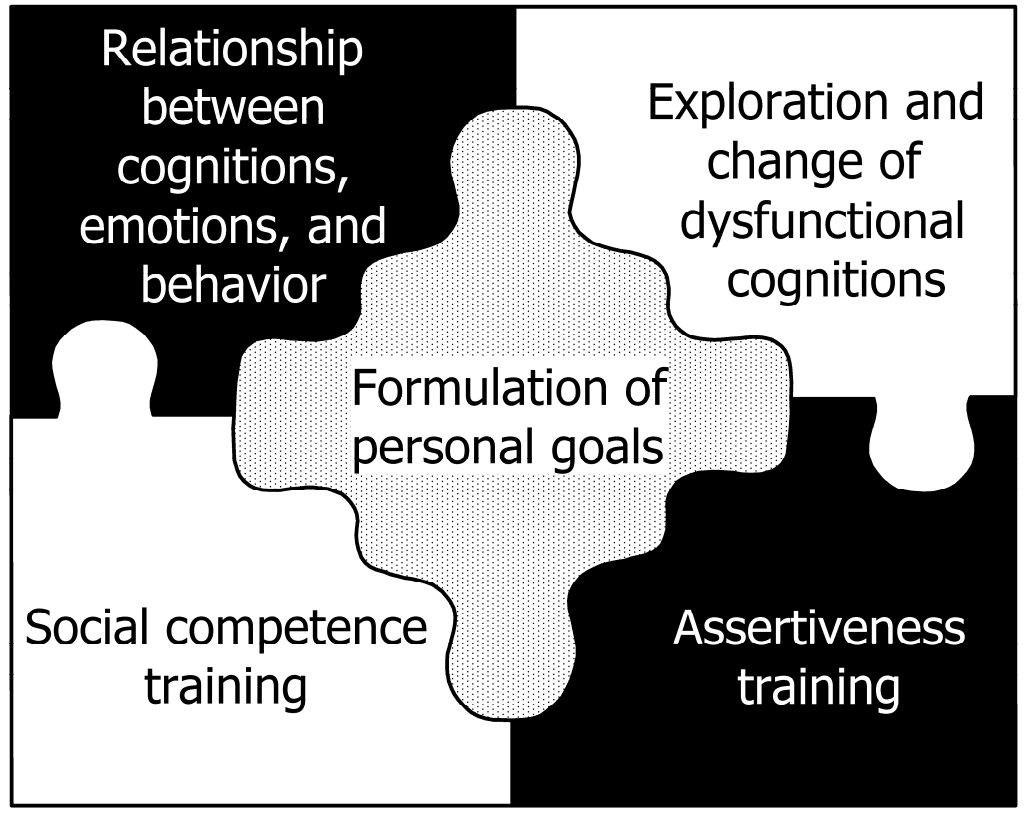


Overhead 3.4 / Worksheet 3.4

Thougts, feelings and behaviour influence each other

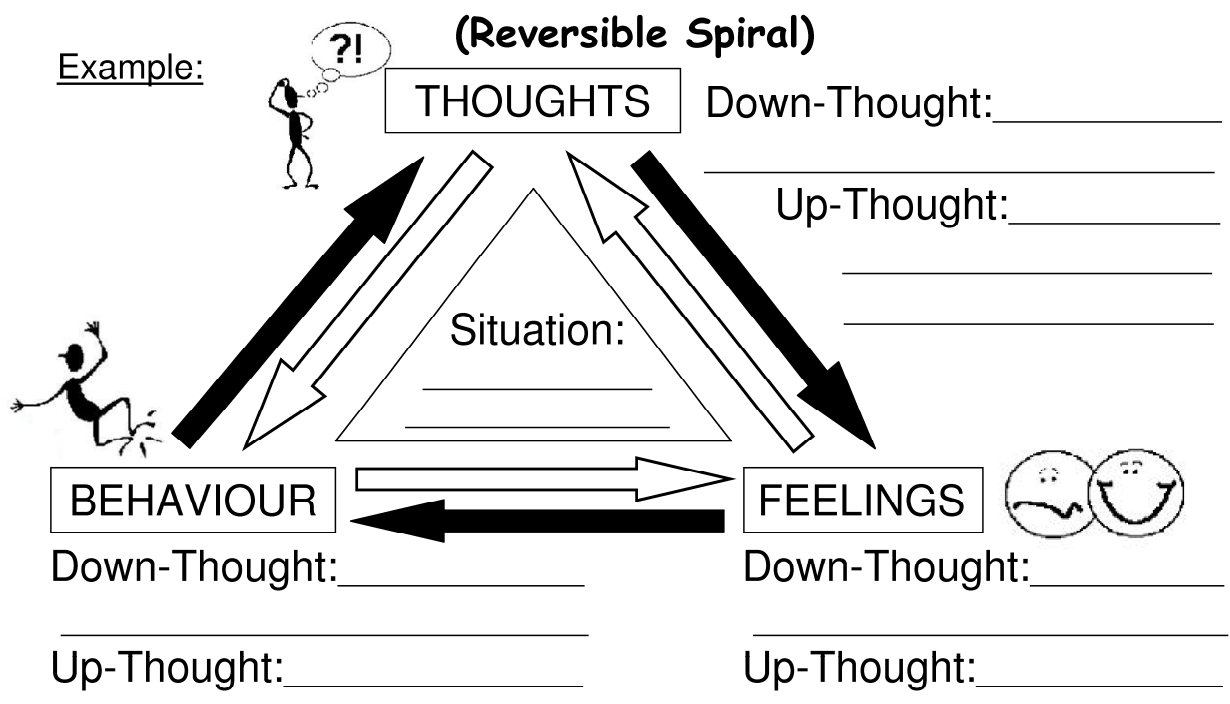


Overhead 7.3 / Worksheet 7.3

\section{Signs of passive behaviour}

Voice:
Eye contact: $\_$
Body language:
Speech content:

\section{Signs of _aggressive_ behaviour}

Voice: _

\section{Signs of _assertive behaviour}

Voice:__ Eye contact: _


Table 1: Contents of the LARS\&LISA prevention programme

\begin{tabular}{|c|c|c|}
\hline Session & Title/Main Topic & Content \\
\hline 1 & Get started & $\begin{array}{l}- \text { Introduction } \\
-\quad \text { Presentation of the group guidelines: fairness, support, and } \\
\text { teamwork } \\
-\quad \text { Consequences of guideline-breaking } \\
-\quad \text { Explanation of the goals and main components of } \\
\text { LARS\&LISA }\end{array}$ \\
\hline 2 & Set your goals & $\begin{array}{ll}\text { - } & \text { Defining personal goals } \\
\text { - } & \text { Formulation and operationalisation of personal goals }\end{array}$ \\
\hline 3 & Reversible Spiral I & $\begin{array}{l}\text { - Defining "feelings", "thoughts" and "behaviour" } \\
\text { - Discussion about the associations among feelings, } \\
\text { thoughts and behaviour (the "reversible spiral") } \\
\text { - Introduction of the concepts "down-thoughts" (self-critical, } \\
\text { negative thoughts) and "up-thoughts" (self-supportive, positive } \\
\text { and realistic thoughts) }\end{array}$ \\
\hline 4 & Reversible Spiral II & $\begin{array}{ll}\text { - } & \text { Identifying the signs of a down-thought } \\
\text { - } & \text { Exploring the meaning of a down-thought }\end{array}$ \\
\hline 5 & THINK I & $\begin{array}{l}\text { - Introduction and training of the "reality check" } \\
\text { - } \quad \text { Creating one's own up-thoughts }\end{array}$ \\
\hline 6 & THINK II & $\begin{array}{l}\text { - } \quad \text { Review meaning of up-thoughts } \\
\text { - } \quad \text { Clarify the need for up-thought training } \\
\text { - } \quad \text { Identification of daily situations into which up-thoughts may } \\
\text { be integrated }\end{array}$ \\
\hline 7 & Just do it I & $\begin{array}{l}\text { Identification of the signs of assertive, passive, and } \\
\text { aggressive behaviour } \\
-\quad \text { Discussion of the pros and cons of different behaviour } \\
\text { styles } \\
-\quad \text { Exploration of the association among down-thoughts, up- } \\
\text { thoughts and assertive, passive and aggressive types of } \\
\text { behaviour }\end{array}$ \\
\hline 8 & Just do it II & $\begin{array}{l}\text { - Demonstration that assertive behaviour can be learned } \\
\text { - } \quad \text { Role-play to exercise assertive behaviour }\end{array}$ \\
\hline 9 & Get in touch I & $\begin{array}{l}\text { - Demonstration of verbal and nonverbal strategies to signal } \\
\text { interest in others } \\
\text { - Role-play to practice "get in touch" }\end{array}$ \\
\hline 10 & Get in touch II & $\begin{array}{l}\text { - } \quad \text { Role-play to practice "get in touch" } \\
\text { - } \quad \text { Review and evaluation of the main LARS\&LISA } \\
\text { components } \\
\text { - } \quad \text { Group members evaluate training and indicate what they } \\
\text { would change } \\
\text { - Wrap-up }\end{array}$ \\
\hline
\end{tabular}

